\title{
Africa in 2108: A Strategic Plan*
}

\section{Mueni wa Muiu**}

\begin{abstract}
What will Africa look like in 2108? Following the present trend, four developments may be in place. First, given the rate of AIDS, conflict and starvation, the population (which is already very small) might be exterminated. Second, extermination of the African population will make room for other people to settle on the continent thus fulfilling Leonard Barnes', Stanislave Andresky's and Stephen Smith's predictions. Third, resources will be exhausted which might mean the end of conflict. Fourth, 'tribal clashes' which result in genocide of threatening ethnic groups may become the norm. This paper argues that these four developments will not occur. Instead, neo-liberal policies which are forcing Africans to live in inhumane conditions will be so dehumanizing that in the end they will provoke Africans to search for genuine development alternatives, regardless of the cost (a process that is already in place). Similar to the days of slavery when conscious citizens throughout the world fought against it, in the age of technology these citizens will not sit by and allow any institutions to implement policies that relegate Africa to a '4 ${ }^{\text {th }}$ world' where conflict, disease, starvation and undevelopment (loss of earlier economic development achievements, for example, education and healthcare as well as the rise of inequality, and moral decay) become the norm.

While current trends tend to marginalize institutions, especially the state in development, we argue that for Africans to overcome the destiny carved
\end{abstract}

\footnotetext{
* I would like to thank the anonymous reviewers whose comments improved the quality of this article.

** Department of Social Sciences Winston-Salem State University Winston-Salem, North Carolina, 271 10.Email: Muium@wssu.edu; Kandakeamrisi@yahoo.com
} 
for them by globalization - as labourers and bystanders in their own development - they have to reconstitute their institutions based on their culture and history. Only a united Africa can harness its resources for development and fair trade in an age of endemic exploitation and corruption. This paper argues that Africa's future will depend on a revision of state borders, increase in population and the creation of a Federation of African States based on five states. In this article a strategic plan is presented by way of 'Fundi wa Africa: Toward a New Paradigm of the African state'.

\section{Résumé}

A quoi ressemblera l'Afrique en 2108 ? Par rapport à la tendance actuelle, quatre nouveaux développements peuvent se présenter. Premièrement, étant donné le taux de sida, les conflits et la famine, la population (qui est déjà très réduite) pourrait être exterminée. Deuxièmement, l'extermination de la population africaine permettra à d'autres personnes de s'installer sur le continent, correspondant ainsi aux prévisions de Leonard Barnes, de Stanislave Andresky et de Stephen Smith. Troisièmement, les ressources seront épuisées, ce qui pourrait signifier la fin des conflits. Quatrièmement, les « conflits tribaux », qui aboutissent au génocide des groupes ethniques menaçants, peuvent être la norme. Cet article soutient que ces quatre développements ne se produiront pas. Plutôt, les politiques néolibérales qui contraignent les Africains à vivre dans des conditions inhumaines seront si déshumanisantes qu'en fin de compte, elles pousseront les Africains à chercher de véritables alternatives de développement, quel que soit le coût (un processus qui est déjà en place). Comme à l'époque de l'esclavage lorsque des citoyens conscients à travers le monde entier ont lutté contre l'esclavage, les citoyens de l'ère de la technologie ne vont pas s'asseoir et laisser les institutions mettre en œuvre des politiques qui relèguent l'Afrique au «quart monde » où les conflits, les maladies, la famine et le non-développement (la perte des acquis en matière de développement économique, par exemple, l'éducation et les soins de santé ainsi que l'augmentation de l'inégalité et la dégradation morale) deviennent la norme.

Alors que les tendances actuelles sont de marginaliser les institutions, particulièrement l'État en développement, nous soutenons que pour que les Africains puissent vaincre le destin qui leur est sculpté par la mondialisation, comme des ouvriers et des spectateurs dans leur propre développement, ils doivent reconstituer leurs institutions sur la base de leur culture et de leur histoire. Seule une Afrique unie peut exploiter ses ressources pour le développement et le commerce équitable à une ère d'exploitation et de corruption endémiques. Cet article défend l'idée que l'avenir de l'Afrique 
dépendra de la révision des frontières entre les États, de l'augmentation de la population et de la création d'une Fédération des États Africains sur la base de cinq états. Dans cet article, un plan stratégique est présenté à travers « Fundi wa Africa: Toward a New Paradigm of the African state ».

\section{Introduction}

Various studies have been done both by Afro-pessimists, optimists and others who were in between. This paper presents Africa's strategic plan for 2108 by way of a theory. Fundi wa Africa's (of Africa in Kiswahili) main focus of analysis is the state, defined as a multilayered entity from grass-root organizations to the leadership. The core of the state is the people who reside within its boundaries. It is informed by diverse ethnic groups' culture, history and environment. The approach includes historical, political, economic, and cultural analysis; it also looks at the impact of population control on Africa's development.

The emphasis placed by this work on indigenous African political systems is not meant to glorify a so-called 'golden age'. Rather, it is designed to identify the still functional elements of those systems and institutions which could be used as building-blocks to re-construct a popular and developmental (that transforms people's lives for the better) modern African state. In principle, Fundi can be used to analyze any African country such as Algeria, Cameroon, Ghana, Kenya, Mozambique, Nigeria and Sudan, to name a few. Fundi can even be used outside the continent to study any former colony in which an indigenous population still exists, such as Brazil, Bolivia, Haiti, Indonesia or Iraq. All these countries experience basically the same conditions, such as poverty, disease and conflict; they only differ in terms of degree. In African countries, such conditions are more extreme and the stakes are higher than in most third world countries because Africa is the largest continent in the world, has abundant natural resources, and is under-populated. Fundi can also be used to explain why though Ethiopia and Liberia were always independent, they were never able to industrialize.

Fundi wa Africa differs from the Statist approach in that (a) it analyzes the creation and evolution of the African state (from indigenous to colonial and post-colonial), (b) it shows how internal and external events and actors in Africa shaped the state and its leadership and (c) it prescribes what the ideal state and its leadership (as determined by Africans themselves) should be. Fundi examines the nature and structure of 
the African state and tries to answer the following questions: how was the African state shaped? What values inform it, and what type of relationship between the rulers and the ruled does it favour? Unless the state is subjected to much greater, in-depth scrutiny and analysis, African studies will continue to deal with form rather than substance.

Thus, if the Japanese state reflects Japanese values, the American state American values or the French state French values, why should African states not reflect African values? Are African values authoritarianism, conflict, corruption, dependency, disorder, hunger and war? In order to meet African peoples' specific priorities and needs, the state must be reconfigured by retaining its positive (and adequately functioning) elements and by incorporating the still functional remnants of indigenous African institutions. In essence, the nature of the African state determines the framework of its economic, political and social interaction with the sub-regional, regional and international environment. Such an approach implies that the state becomes the main unit of analysis and the central focus of our study.

\section{Fundi wa Airica as Theory}

This paper argues that African state structures and their relationship with Western countries are the root causes of the African predicament. 'West' here does not imply that Western societies are homogeneous. They are made up of people of different social classes, races, ethnicities and religious beliefs. Similarly, Africa is not viewed as a homogeneous geographic, environmental and socio-political entity. For example, West Africa (especially the Sahel region) is very different from East, Central and Southern Africa. Under the influence of Islam, most African institutions have thrived alongside Western-imposed ones. Furthermore, Islam and Christianity have affected African culture in different ways. In some cases, the worst of indigenous African culture has been retained, for example when super-natural powers are used to destroy life or cause conflict. Using the pretext of tradition, people may depend on their neighbours to provide for their basic needs without any sense of shame. Yet, dependency and laziness were unacceptable values in African culture. Another disturbing feature is the survival of the caste system (based on inherited socio-professional specialization) in some regions of Africa, such as Sahelian West Africa. This system is so entrenched in these communities that members of the so-called 'lower' castes (such as griots, 
blacksmiths or leather-workers) are not given much room to grow and prosper outside their own caste. Geographically and environmentally, there are also huge differences between the desert, the savannah/Sahel, and the forest.

By 'African' is meant any person who identifies as such and considers Africa as their home. In this study, 'Africa' refers to all 54 states on the African continent, including Western Sahara and the Indian Ocean island states. African states vary greatly in size, natural resource endowment, environmental features and population. However, the appalling socio-economic conditions facing the majority of the population (conflict, low life expectancy, disease, famine, poverty and unemployment) and the exorbitant privileges enjoyed by the ruling elite (obscene wealth, foreign bank accounts, conspicuous consumption, children studying, and families shopping abroad) are much the same throughout the continent. This predicament puts Africa at the lowest level of economic, political and social development in the world. One striking feature of the African predicament is that the ruling elite typically constitutes no more than two per cent of the population, yet enjoys full citizenship rights, as well as freedom from hunger, disease, fear and conflict. This ruling elite which maintains an expensive, western-type lifestyle in the country's capital city - remains totally indifferent to the plight of the majority of the people, who are at their mercy. Fundi contends that one cannot understand the African predicament without analyzing African indigenous political systems, as well as the colonial and neo-colonial states. Successive historical processes such as slavery, colonialism and neo-colonialism (an on-going process renamed 'globalization') contributed to the creation of the present African state, which reflects the Western state but fails to perform the same functions.

This paper argues that this Leviathan is a monster which functions as an agent of exploitation of the people by both African rulers and the West. The present crisis facing the African state, which manifests itself through AIDS, conflict, foreign indebtedness, eugenics population policies and un-development makes it impossible for the African state to attain autonomous, self-sustaining development. The present state is not conducive to development because its nature - an exogenous structure without Africans' interests, priorities and needs at heart - and its relationship with the West do not allow for any type of autonomous, popular development. In reality, the African state has been constructed 
in such a way that dependency on the West is inevitable. The way out of this predicament is to replace the present African state with the still functional positive elements of African indigenous institutions in order to create a state that can be both autonomous and democratic. Such a development cannot occur without the people's participation, hence the introduction of Fundi wa Afrika. It is believed that no one has used such an approach before. Mueni wa Muiu decided to apply it to study the nature of the African state after she observed the building process in a small village in eastern Kenya. The owner of the house determined what the needs of the family were, and explained this to the builder. Throughout the building process, the builder and the owner consulted each other. Whenever any modifications were required, the builder effected them according to the client's needs and instructions. Muiu noticed the same process when she took her material to a tailor for a suit to be made. The tailor would ask Muiu what her needs were, and they consulted each other throughout the tailoring process, which would only be completed when both were completely satisfied with the final product. It is then that Muiu realized that the relationship between Africans and their institutions in indigenous Africa was similar to the building and tailoring processes. In those days, the leaders were attentive to their people's priorities and needs, and they would fashion the political institutions accordingly. Muiu then decided to study the evolution of these institutions to understand when and how they changed to be externally-determined rather than being defined by indigenous factors.

Fundi wa Africa is a new paradigm in African studies. By 'paradigm' is meant, according to Thomas Kuhn, a model of scientific practice that some particular community acknowledges for a time as supplying the foundation for its further practice and attracting a group of adherents away from competing modes of scientific activity. At the same time, this new paradigm is sufficiently open-ended to leave to this group all sorts of problems to resolve (Kuhn 1997:10). The socio-political and economic conditions facing the majority of Africans developed over many centuries and obviously cannot be changed within a short time-frame. Political and economic transformation will take a very long time and is likely to involve conflict because the indigenous and foreign beneficiaries of the present system will fight to maintain the status quo. 


\section{Fundi wa Airica in Practice}

The main practical aspects of Fundi wa Afrika may be summarized in 15 points.

1. Fundi wa Africa argues that the African state must be reconstructed based on African culture, history, traditions, priorities and needs (however these are defined by Africans). It uses history to demonstrate that African political systems were radically and permanently altered after slavery to serve minority and Western needs. To reverse this trend, Africans must first recapture their economies. Such a development implies Africans' control over the resources within their borders for the sole benefit of every African child, man and woman. Fundi wa Afrika argues that any other plan is only a distraction which draws Africans' energy away from constructive purposes and toward dependency and destructive activities. African people must also realize that they have to take ownership of their own development and democracy. Western countries and their African associates, like any other group, protect their own interests to the detriment of the majority of the people. The dependency of the majority of the population on religious fatalism, corrupt African leaders, or predatory Western countries will only result in bankrupt development models, moral decay and poverty. An astute observer of Western societies, the French publicist Alexis de Tocqueville, observed as far back as 1835 that:

If we reasoned from what passes in the world, we should almost say that the European is to the other races of mankind, what man is to the lower animals; he makes them subservient to his use; and when he cannot subdue, he destroys them (Tocqueville 1835:179).

In 1921, René Maran deplored the heavy cost in human lives of the French 'civilizing mission' (mission civilisatrice):

Civilization, civilization, pride of the Europeans and graveyard of innocents, you build your kingdom on cadavers. You are the force that prevails over the law, you are not a guiding light, but a wild fire (Diop, O. T. \& F.X. Verschave 2005:33-34).

In the same vein, Leonard Barnes argues that

The NATO countries are no longer able to give. They cannot give at all, in the sense of behaving with a measure of yielding deference in 
those whose value-systems differ from their own. Nor can they give at all, in the sense of showing generosity united to calculations of their own advantage. Beyond a punch in the face from their power, they have nothing, therefore, to offer to anybody (Barnes 1969:55).

Wayne Madsen concisely sums up America's contemporary Africa policy:

America's Africa policy is morally corrupt. Its commercially-influenced orientation has directly promoted ethnic rivalries and some of the worst bloodshed of the $20^{\text {th }}$ century. U.S. military and intelligence involvement in Africa, far from creating a sanguine and stable environment for a 'new world order,' has taken the continent back to another era, namely, the 'old world order' of Western tutelage, tribal preferences, commercial chicanery, and continued underdevelopment (Madsen 1999:478).

The interests of Africans differ from those of Western countries. The former want to live in dignity, economic self-determination and peace, while Western countries want cheap labourers - who accept an inferior position in a Western-dominated world - and markets for their goods. Western countries also want to exploit Africa's natural resources. Given the nature of the relationship between African and Western states, the former cannot industrialize unless the process is controlled by a small white minority, as is the case of South Africa. Furthermore, conflict, war, disease and epidemics will depopulate the continent to such an extent that it will never be able to compete in the international economy. According to Stanislav Andreski, African countries and peoples will eventually self-destruct under the combined impact of war, famine and disease, acting as efficient checks on population growth:

In any case, so long as the birth rate remains at the present level, war, famine and disease will continue to play the role of checks to population growth with increasing efficacy. Which of these checks will be more important will depend on the circumstances; and we might see either endemic warfare (internal or external) or harsh despotisms holding down their subjects in such misery and degradation that the victims of disease, hunger, terror and crime will be sufficiently numerous to compensate for the high birth-rate (Andreski 1968:212 the author's emphasis in italics).

In other words, according to some Western experts, the main problem with Africa seems to be the Africans themselves. As Barnes noted back in 1969: 
If it were possible to empty the continent of Africans and replace them with much smaller numbers of say, Chinese or Japanese or even Americans, the mise-en-valeur [development] of these desperately illused territories would proceed at a pace and in a relatively orderly fashion of which there is no current prospect (Barnes 1969:11).

Stephen Smith makes a similar argument:

If, by some kind of population replacement program, the population of resource-poor Japan could replace that of oil-rich Nigeria; or the population of France could replace that of the Democratic Republic of Congo, then the future of the 'giant of sub-Saharan Africa' or that of former Zaire would be secure. Similarly, if six million Israelis could replace an almost equivalent number of Chadians, flowers would bloom in the Tibesti desert and an African Mesopotamia would emerge in the fertile lands between the rivers Logone and Chari [in Chad] (Diop O. T. \& F.X. Verschave 2005:19, 82-3).

Similar to the days when slavery was the norm and citizens rose against it, in the age of globalization some citizens have taken measures to halt the destructive nature of globalization. These citizens (both local and international) have formed associations to empower themselves. For example, when banks in Ghana, Kenya, Uganda, Tanzania, Nigeria and South Africa denied loans to clients who lacked collateral, these citizens created their own fund-raising organizations which empowered them economically. Similarly, to counter foreign security firms which only protected Europeans, local citizens created their own firms for protection. Africans who live in the Diaspora have also realized that sending funds home is not enough. Instead, they are investing in property whereby they have replaced foreign capital in some cases. As Africans in the Diaspora continue to have dialogue with those on the continent, many are forced to question the viability of the Western-imposed type of development. A new movement is developing which forces these Africans to seek alternative ways of empowering themselves. In the Democratic Republic of Congo where capitalist greed is out of control, citizens have created their own sources of electricity, organized trade and security. It is interesting to note that these movements are developing as a result of the economic disempowerment and moral decay that Western tutelage has produced in these states. These contradictions have forced some Africans to fight for their own liberation as they travel from country to country where the stark realities of uneven development are laid bare. 
2. Every legitimate state's first priority must be to halt the progression of debilitating diseases still endemic in Africa, particularly AIDS, malaria, sleeping sickness (trypanosomiasis), river blindness (onchocerciasis), bilharzia (schistosomiasis) and tuberculosis. This means that leaders will not allow their populations to be used as human guinea pigs by pharmaceutical companies, nor will they spend excessive amounts of money on the military at the expense of their people as is the case in Botswana, Kenya, Uganda and South Africa. In four conflict-affected central African countries (Angola, Congo, the Democratic Republic of Congo, and Gabon), WHO (World Health Organisation), UNICEF, and the CDC (Center for Disease Control \& Prevention) launched the firstever synchronized massive polio immunization campaign with the aim of vaccinating 16 million children between July and September 2001 (All Africa.com). At the time of writing a combined effort between the Centers for Disease Control \& Prevention and the World Health organization is vaccinating the Cote D'Ivoire's citizens in conflict areas. A leadership that abandons its people to disease and exploitation is illegitimate. Legitimate leaders are those who know (and are responsive to) their peoples' basic needs. First, they meet those basic needs (such as security, food and health). Second, these leaders listen to their people, they consult them on all major political and economic decisions. Third, such leaders do not need to be protected from the people because they are one with the people. Fourth, such leaders also consult with local - as opposed to foreign - advisers who have African interests (whichever way these are defined) at heart. Fifth, such leaders do not steal from the people. Instead, they protect and defend the wealth of the nation for the common good, a feature that existed in indigenous political institutions. 3. Africans should connect rural (where the majority lives) with the urban areas on the basis of African culture. The current class formation prevents a reconstitution of the state because the elite is divorced from the peasantry (a process that began with slavery). Transformation cannot occur within the present class structure without conflict developing, since the interests of the elite differ from those of the poor. No people can develop within a foreign culture. If Africans are to control their destiny, they must do so within their own culture. Africans have to take another look at their history to borrow what worked in indigenous Africa and merge it with Western institutions. Indigenous institutional safeguards such as checks-and-balances on leaders' powers would benefit contemporary African states. Civil society organizations must be based 
on the African reality and on indigenous social structures such as agegrades. Decentralization of political power must be integrated into the present state system. African leaders should take a leaf from the rural sector to learn what past institutions could work in contemporary Africa. Thus, the Ruwenzururu - a peasant guerrilla movement of the Bakonzo and Bamba on the Uganda-Zaire border active from 1962 to 1980 - organized peasant communities into popular assemblies with supervisory powers over state functionaries. The village assembly - which included all adult villagers - had the right to appoint, censure or acclaim the chief, without any state interference or intervention (Mamdani 1996:197-200, 206-7).

According to Fundi wa Afrika, Africans must realize that only their efforts will change the conditions facing them. The people must know that no single individual, however famous, will save them. Everything depends on them. Once the political arena has been demystified through political awareness, Africans will identify with a reconstituted state. Such a state becomes theirs. They will not steal from it because they have made it. They can change it whenever they choose to because it is based on their interests. This liberating awareness becomes a driving force for improving the conditions facing them. It also removes the Africans' dependency syndrome (whether on leaders, deities or the West).

Fundi wa Afrika does not assume that culture is constant but views it as a dynamic force that changes according to the conditions facing it. It does not assume that all African culture is valuable, just like not all Western culture is positive. Some aspects of African culture have been used to dispossess Africans. For example, the openness of Africans to strangers has resulted in some people taking advantage of Africans. Africans' trust of others to have their best interest at heart is a weakness that continues to inform contemporary culture. This aspect of African culture must be discouraged. In other words, Africans must prioritize their interests - however defined - over those of others. As any other society does, Africans must rely and build on the best of their own culture to recreate the state. They must incorporate modern technology into the positive aspects of their culture. Mimicking the West only exacerbates Africa's poverty, as is currently happening under the guise of democracy, civil society, liberalization, the rule of law and globalization. Such mimickry perpetuates a process of destruction of African indigenous institutions which began with the trans-Atlantic slave trade. The colonial state cannot possibly be reformed. It has to be totally destroyed. 
How can a rotten mango tree produce mangoes? Africans must ask themselves: whose democracy, whose liberalization and whose globalization are we talking about? They will discover that all these slogans mask a ploy to control African resources. By focusing on the rural sector, the African state will stop the rural-to-urban migration which has left the former in stagnation. Production must be focused on domestic needs rather than being export-oriented. Such an orientation implies that the first priority would be like in any other modern state: to meet the basic needs of the people.

4. Africans must transform the educational system. Under colonial education Africans were trained in irrelevant fields that were not informed by their culture and environment. Education was too theoretical. It was too centralized in urban centres, thus neglecting villages. Western education in Africa alienates Africans from their culture and environment. It presents Africans as people without any positive tradition, culture and history, people who were always 'backward', weak and dependent until Western colonialists and Christian missionaries came to save them. This misrepresentation must be countered if Africans are to be free. Civic education will be crucial in creating an African state. Such an educational system encourages students to be innovators and educators rather than passive consumers of information. It can integrate African oral tradition, art, history with science and technology to prepare Africans to deal with their environment and the conditions facing them. Such an education would use a new type of pedagogy. For example instead of students sitting in a classroom facing the teacher, the African circle that was used for story telling could be introduced. Students would sit in circles with the teacher - acting as a facilitator of knowledge - at the centre, in the belief that students learn in different ways. Furthermore, education should directly relate to the students' reality rather than alienating them from their environment. Thus, colonial education discouraged Africans from studying science and mathematics. The new educational system must emphasize both disciplines. Schools of mines and engineering must be introduced throughout the continent to teach Africans how to exploit their resources. The abridged and popularized version of the 8-volume UNESCO General History of Africa can be used as a starting point for teaching history. Compulsory universal education must be introduced throughout Africa. No society can develop without its youth. Any keen observer visiting African countries from Cape Town to Cairo will be shocked by the number of idle youth. Fundi wa Africa ar- 
gues that any plan that condemns a society's youth to social, moral and cultural decay - such as that currently proposed by the IMF and the World Bank - must absolutely be rejected.

5. Without the proper leadership, Africa is lost to Africans. Throughout African history, African leaders were active either as heroes or collaborators. The system of collaboration continues today. The new leadership's first priority must be to meet the needs of its subjects. Democracy in Africa must serve the interests, priorities and needs of the majority. Any leadership that does not fulfil this role is illegitimate. Enforcing the popular will must be the guiding principle of a good leader. No leader should abandon its people to indignities justified as the 'rule of law'. Whose law is it, anyway? If such a law is a mere pretext to exploit the people, then nobody should abide by it. Africans must search their history to understand how leaders were chosen, trained and prepared for leadership based on tradition and culture. The new African leadership should exhibit the following characteristics. First, it must have Africa and its people as their only priority. Second, it must be chosen from each level (village/town council, national and federal) based on ideals and principles that the people themselves will decide on. Third, the performance of the leaders will be judged based on what they have done for the people rather than how long they have been in office. Constitutions (whether written or oral) will have provisions that allow for the people to remove a leader from office before the end of a term if such a leader is deemed unsuitable or corrupt. Such a leadership can only develop within a reconstituted state and as a result of the transformation of education. This explains why Africans have to achieve this objective without any foreign interference.

6. Any system that condemns women to violence, poverty and disease must be overhauled. Most indigenous African political systems respected women. But this changed under colonialism. African states must put women back in their rightful place in society as economic, political and social actors. In indigenous systems, women had a choice in polygamous marriages. Women should not be forced to enter into polygamous marriages unless they choose to. Democracy is about choice. Lower-income women have been the victims of the IMF/World Bank Structural Adjustment Programs as states drastically cut down their expenditure on health care, education and other social services. Women have also been affected by globalization because they are the worst paid in the world economy. They continue to constitute the majority of AIDS victims. 
African women's liberation must be based on the positive aspects of indigenous institutions rather than being carbon copies of Western feminism. Women are the heart of Africa's future. Without women, Africa is lost to Africans. African women will be the driving force of Africa's political, economic and social development.

7. In the context of globalization and of the world economy, African countries must be selective in their trade policies in order to develop their human resources behind protective barriers. It is crucially important that Africans create their own companies which will operate throughout the Federation and will be given preferential treatment over foreignowned companies. All foreign companies operating within the Federation will be forced to pay taxes and to re-invest their profits locally. In a reconstituted state, African leaders have to introduce measures that protect workers against exploitation by trans-national companies such as limited working hours, minimum wages, pensions and medical insurance. Furthermore, companies operating in these countries must not be allowed to create tax-free zones which operate as enclave economies and discriminate against the local people. A National Development Fund (NDF) will be created. Each foreign firm will be required to deposit a percentage of its annual revenues - say, ten per cent - in the NDF. Instead of relying on foreign experts, African countries working within a reconstituted state will rely on African expertise. The disconnection between African leaders and African professionals and civil society/grassroot organizations in contemporary African states is striking. African leaders do not work with African professionals to create policy. Instead, there is tension and competition between the two groups, a process that began with the onset of the trans-Atlantic slave trade. This process can only be reversed within a reconstituted state.

8. In the reconstituted African state, the activities of Non-Governmental Organizations (NGOs) will be circumscribed and strictly regulated. In African countries today there are far too many NGOs, each operating according to different agendas, often to the detriment of the people. Some of the activities of these NGOs - especially those engaged in birthcontrol programs - are highly questionable. A reconstituted state will introduce laws and regulations that will ensure that the activities of these organizations adhere to the interests, priorities and needs of Africans. 9. No development can occur without an efficient transportation system. Roads, railways and air routes should be conceived to connect Afri- 
can states to each other. Communication and telecommunication networks must be geared toward the inter-African movement of people and goods' needs rather than toward the former colonial countries. Once internal transportation is improved, trade will increase as different regions trade with each other on the basis of complementarity. For example, Senegal imports nearly all its food. Milk and fruit juices come from either France, Italy or Portugal. Fruits are imported from either Morocco or South Africa. From October each year, lettuce must be imported because none can be produced domestically. In a reconstituted state countries located in the Sahel will trade with East, Central and Southern Africa in various goods. For example, countries of the Sahel are known for their beautiful cloth, artwork and oil. They can export these to central, east, and Southern Africa in exchange for food products. These countries will also trade in minerals. Each region will concentrate on what it produces most efficiently without manufacturing goods produced in other regions. Just as the indigenous system in which different areas such as forest, savannah and the Sahel - complemented each other, the reconstituted state will do the same. Regions best suited for agriculture will concentrate on food production while the Sahelian regions will focus on textiles and clothing, minerals and fossil fuels and services. Thanks to the freedom of movement of people, goods and capital, expertise will be widely shared by all the states and all the regions.

10. Africans cannot have a reconstituted state without a comprehensive cultural policy in the area of radio and visual arts (including television and film). A uniform policy must be introduced that sets standards for radio and television programming, as well as for film production. A supervisory board will examine each film proposal to make sure that the films produced in (and distributed on) the continent do not denigrate Africans, do not demean African culture and do not undermine African values. In the reconstituted state, no foreign-owned radio or television station will be allowed to operate, as is currently happening in Botswana, Kenya and South Africa. The state should sponsor artists, film-makers, and writers to produce their works in total freedom and without any ideological bias. Foreign soap-operas which seduce the poor with the artificial glamour of Western luxury without providing the means for these people to achieve their goals should be discouraged. Decolonization of the media will take various forms. First, African culture which has been relegated to tourism must take centre stage in the Federation's development. Second, foreign soap operas which are provided free of 
charge have to be replaced by locally produced ones (a process in place as Nigeria 'Nollyhood' films become popular). Third, tribal radio stations (for example, as happened in Rwanda in 1994 and in Kenya in December 2007) which are used to promote inter-ethnic hatred can be replaced with African-oriented radio stations. In the Kenyan clashes hate messages were also transmitted through text messages (NPR 2008: February 20; Economist 2008:5 1-52).

11. A reconstituted state must protect children and the youth (from age 0 to 18). The traveller to such countries as Angola, Congo (DRC), Kenya, Botswana, Uganda, Nigeria, Senegal, Sierra Leone and South Africa is struck by the number of young children who engage in prostitution. In most of these countries, pornographic material is not restricted. Another common feature of these countries is the number of foreign and local men and women who engage in sexual activities with children. Most of these countries have become havens for paedophiles who get away with activities that are severely sanctioned by law in their home countries. Except for Burkina Faso and Senegal, judicial systems in most African countries have ignored the impact of paedophilia on the fabric of their societies. Heavy penalties must be introduced to punish paedophiles as well as older men and women who engage in sexual activities with children. As the incidence of AIDS increases, another very disturbing development is the number of men - in such countries as Malawi and South Africa - who rape babies in the belief that these babies will cure them of the dreaded disease. Some have cloaked this despicable activity under the mantel of 'African culture'. There are absolutely no instances in indigenous institutions where infants were violated in this manner. Current justice systems do not protect these infants and children. A reconstituted state must impose prohibitive fines on any group or individuals that promote the violation of children's lives under the pretence of African culture, tourism or religion.

12. A reconstituted state must also protect girls from genital mutilation, a practice carried over from ancient Egypt and Kush. In some areas of Guinea the rituals, which mark girls' rites of passage, have been retained without resorting to mutilation. African states can still allow the rituals to be practiced but without the mutilations which have caused so much death and suffering. The goal of the reconstituted state is to retain the positive aspects of African culture while acquiring relevant technology for development. It cannot do so without protecting girls from medically unsound and dangerous practices. 
13. Most African cities have failed to substantially increased the electricity, water and sanitation infrastructure which they inherited from colonial governments. No development can occur without a beautification and sanitation department in every region. The main goal of such a department will be to make sure that water is available at all times by creating water reservoirs. Furthermore, cleaning programs must be put in place whereby garbage is disposed of properly and recycling centres are created throughout the region. A cleaning program (similar to that of Shaka Zulu) must be introduced in which each resident is responsible for keeping their private quarters and their cities clean because it is 'their' city. There is nothing traditional about unsanitary conditions. It is a terrible habit that smacks of irresponsibility and lack of accountability. Africans have always kept their villages clean. Why do they lose this quality when they move to cities? Any beautification and sanitation program should include taking care of the homeless people who populate African cities from Cape Town to Cairo. A reconstituted state must build affordable housing for the homeless and provide job training, for example, in crafts and education. In Dakar (Senegal), people, goats, and sewage compete for swimming space in the ocean. During the rainy season, sewage fills some streets for days. In Nairobi (Kenya) Kibera and Mathare have become rubbish dumps. Pikine (Dakar, Senegal), Guguletu and Kayelithsha (outside Cape Town) do not fare better. A state that is managed by the right leadership will not privatize water to the detriment of the poor. Rather, it will tax companies to provide essential public services for the poor. A reconstituted state must make beautification and sanitation a priority. People must be rewarded for planting trees, creating parks and keeping both private and public spaces clean.

14. Africa cannot be secure without a continental army based on redrawn borders (Map 1: FAS). Each state will contribute a contingent to a standing federal army to protect the continent.

This army will be in a better position than international agencies to respond quickly to internal emergencies and to help relocate refugees. This army will be made up of Africans who consider Africa the first priority. It will have to fight against local and international mercenaries who undermine Africa's freedom. Without a dedicated army, the Federation will not defend itself. It is only when Africans realize that they cannot be paid to kill fellow Africans that they will cease to participate in their own disempowerment. Government institutions will draw on 
African indigenous methods of conflict resolution. They will open avenues for resolving conflict before it arises by providing basic resources, such as land, food, health care and shelter which currently force many people into conflict. The presence of an African federal army will also reduce the role of mercenaries that continue to wreak havoc in these states. Furthermore, each state will maintain its own youth service (a type of national guard) but will rely on the federal army for its security. The army will not be used to oppress citizens; instead it will be fully integrated into, and be in, the service of the community. No foreign military bases will be allowed in the Federation. Hence the need for a mentally-decolonized military leadership firmly rooted in African traditions and values.

15. The African debt must be totally written off, and a moratorium on debt repayment declared. As a block, the Federation must refuse to pay debt. Several developments may occur from the refusal: open war instigated by those who are owed money, outbreaks of diseases like Ebola may become the norm, low intensity warfare where tribal wars act as destabilization forces may develop (as is currently happening in Kenya where the United States and the European Union are forcing Mwai Kibaki to share power with their candidate of choice, Raila Odinga). If Kibaki (who became an enemy of the empire when he signed economic and military deals with China while marginalizing the IMF/World Bank) refuses to share power with Odinga, the organized violence and death will continue. If they are to free themselves, Africans must be willing to face all these challenges.

Ordinary African men, women and children cannot be held accountable ad vitam aeternam for a debt incurred by their unelected elites in pursuit of their own enrichment, and without their people's consent. African leaders themselves are personally accountable for repayment of the debt incurred vis-à-vis their Western lenders and overlords. In this sense, it can be truly said that Africa and Africans owe absolutely nothing to Western countries or their agencies. If anything, it is the West which owes Africans reparations for the millions of human lives lost and billions of dollars of mineral wealth plundered and revenues extracted during five centuries of European predation and exploitation through slavery, imperialism, colonialism, debt repayment, neo-colonialism and globalization. 


\section{Governance and Political Institutions in the Federation of African States}

As a reconstituted state, the Federation of African States (FAS - see Figure 1) will include several levels of authority based on a clearly defined separation of power designed to act as a check on the abuses of power by any one branch of government. The national (federal) government will levy federal taxes for the defence and security of the Federation, as well as for the transportation infrastructure. States will collect state taxes - for state defence, security and transportation - and work with the federal government for the benefit of the Federation. The presidency will be organized on a rotational basis between the different regions. Each president can only serve for two six year-terms (if re-elected for a second term). However, citizens have a right to call a referendum if the president fails to perform her/his duties to their satisfaction before the end of the first or second term. Power will be divided between the presidency, the judiciary and citizens' councils (at the village/town, regional and national levels). No branch of government will be allowed to interfere in the activities of the other or to monopolize power to oppress the people. Each level of governance will be advised by an advisory council.

National ideals, values and goals based on African culture, history and environment will inform every aspect of governance. Unlike liberal democracy that privileges corporate, sectional and elite interests over those of the majority of the people, Africa will have a popular democracy-based on accountability and responsibility - that will be organized from below (Ake 1996:2000). Democracy will only be meaningful in Africa if it allows the people - both those in rural and urban areas - to decide on their destiny rather than allowing corrupt leaders based in capital cities to do so. Since each section of the population will have representatives at all levels of government, power will be decentralized and the people will determine their destiny based on their interests, priorities and needs. Governance will be a bottom-up approach. Power will start from the village councils made up of the local people. This will be followed by a regional council of elders, then a national council who will be followed by the federal council of presidents.

The federal capital of FAS will be based in Napata. Economic and political power will be decentralized, giving people more input in the day-to-day activities of the Federation. The leaders of each of the five states will meet 36 times a year. They will meet in Napata 12 times a year; they will meet in each one of the states on a rotating basis based on 
alphabetical order another 12 times; the remaining 12 meetings will be held in their own states. While in a particular state, leaders will meet with the people in town halls as well as in the state's village councils so that they can find out the needs of that particular state. These meetings will be crucial in decentralizing power between rural and urban areas, therefore encouraging a bottom-up approach where leaders learn from the people.

In FAS, governance will be based on a bottom-up approach where most of the power will belong to the village councils of each state, composed of 120 members elected directly by the people. The people's council (composed of 600 members, 120 per state) shall meet twelve times a year at the federal level. Elections will be based on proportional representation where a candidate's election depends on the actual number of votes received. Members of the village councils would each be in office for terms of seven years, renewable indefinitely. Each would represent the village council at the federal level. The governance of each state is entrusted to a state village council made up of 200 members (also elected directly by the people on the basis of proportional representation). These members would be in office for two 3-year terms (if re-elected). State village councils would work within FAS ideals as laid out in the Federation's constitution. The next level would be the council of elders which would be in office for a maximum of three 5-year terms. The council of elders would have 100 members (chosen directly by the people from diverse professional and age-groups) from each state. The State's council of elders would be in office for a maximum of two 4-year terms. FAS' council of elders will be responsible for advising the House of vice-presidents and the president. The third branch of government would be the judiciary made up of individuals skilled in indigenous as well as western law. Village, provincial, state and national courts (High Organ) would make up the judiciary system.

The penal system would be based on rehabilitation rather than retribution and incarceration. FAS would totally prohibit the death penalty. People convicted of crimes and minor offences would be rehabilitated through community service - such as building/repairing roads, schools, public buildings or wells - for a specific period of time depending on the nature and seriousness of the crime. Discrimination in any form would be punishable by law. Any FAS citizen would be allowed to travel and settle freely throughout the Federation regardless of ethnicity, national origin, race, class or gender. 
Five vice presidents would make up the fifth branch of government. Each state would elect one vice president. Candidates for the vice presidency must be elected by the constituents of the states based on proportional representation and on FAS ideals as stated in the constitution. The vice presidents would serve for an initial 8-year term to be renewed once. The fifth branch of government would be made up by the presidency which would rotate from state to state based on alphabetical order. Six presidential candidates from a particular state will be chosen from and by the village council. They must win a national election in all five states. The candidate receiving the most votes will become the president. Each president would serve for an 8-year term, renewable once. Power would be like a pyramid with the base holding the most influence (see Figure 1). The people shall have the right to remove any elected official from office before his/her term is over by referendum. The Federation of African States will have a constitution which will specify the structure, rights, duties and powers of each branch of government. Members of the village councils, council of elders, and judiciary will draft the constitution with the assistance of the citizens. The people shall approve the constitution by referendum.

Figure 1: FAS Structure Reconstituting an African Identity within the Federation of African States

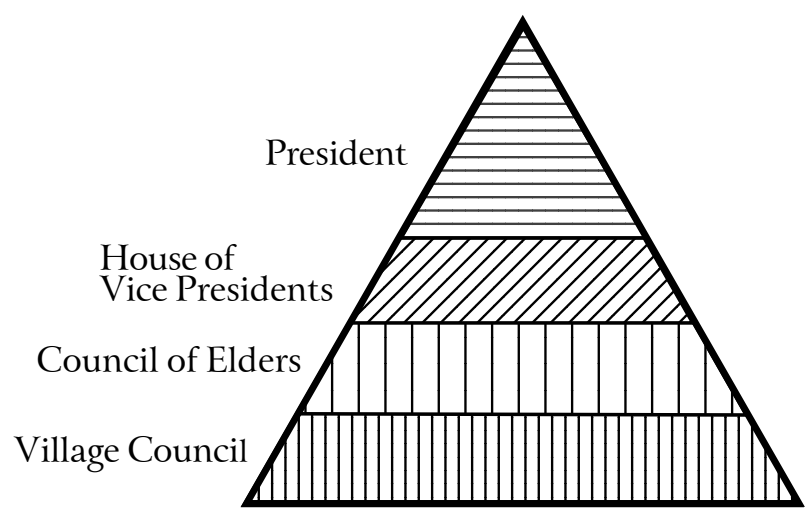

One cannot discuss the reconstitution of the African state without examining its various fragments. First, there is the divide between the indigenous and the modern sector and between various African states with different colonial experiences and traditions. Transportation must be 
improved so that Africans can easily travel within the continent. Currently, it costs more to ship a car from Dakar, Senegal to Cairo, Egypt than it costs to ship one from Japan to Dubai in the United Arab Emirates. Internal transportation will also improve communication between African regions and facilitate trade as goods will be cheaper to transport. Second, ethnicity has been so politically manipulated both by colonial agents and the post-colonial elite that it has become a major source of conflict. Following indigenous notions of identity that respect humanity in spite of differences, Africans must learn to tolerate difference as a source of strength. An educational system that emphasizes an African identity will play a key role in transforming ethnicity from an agent of division of the people to an agent of unity. People can still identify themselves as Arab, Fulani, Maninka, Kikuyu, Yoruba or Zulu as long as that identity is not used to create conflict. Once an African identity is privileged over an ethnic one, Africans will be ready to control their destinies as they live in peace and dignity. Third, a vast gap exists between Africans in the Diaspora and those on the continent. Both must have open dialogues to encourage communication and an understanding based on cultural as well as other differences. Africans must seek other groups in the Diaspora who have the same goals to reconstitute the state. Africans in the Diaspora who support the new state could invest in these states or settle if they wish to. Fourth, a divide exists within the African continent between rich and powerful states (such as Egypt, Nigeria and South Africa) and poor and weak ones (such as Comoros, Djibouti, Gambia, the Seychelles, and Sao Tome \& Principe). This divide also exists between the forest, the savannah and the Sahel. A reconstituted state must complement all these areas as they work together. Fifth, the current African state suffers from a fragmentation of knowledge (Barry 2001). In contemporary African states, there are three types of elites that neither communicate nor complement each other. First, the indigenous elite trained in oral tradition; for example, griots/praise-singers, and medicine men and women. Second, a Muslim/Arabic elite trained to write in Arabic and African languages, as well as a Christian elite. Finally, colonialism introduced its own elite trained in English, French, Portuguese and Spanish at the expense of indigenous languages. A reconstituted state must create avenues where all these elites communicate and work towards the same goal. Unless there is a complementary relationship between these three elites, there can be no economic and political and cultural leadership in Africa. 
Different African states must unite within a Federation of African States (see Map 1: FAS) to create internal markets for African goods and economies of scale. It is interesting to note in this regard that the Organization of African Unity (OAU), at its $5^{\text {th }}$ extraordinary summit meeting in Sirte (Libya) of March 1-2, 2001, formally adopted an African Union, complete with a Pan-African Parliament, Court of Justice and African Economic Community. Unfortunately, what has emerged from the Sirte meeting is not a United States of Africa but another pale imitation of the European Union designed to further open Africa up for exploitation. As has happened throughout history, with the support of the West, African rulers have mortgaged the continent and its people's future to various organizations. During this process, various factions emerged, thus demonstrating the inability of African rulers to think and act independently of their Western sponsors. Such factions included one led by Algeria, Nigeria and South Africa (with the support of United States and the European Union), on the one hand, and the very few which sided with Libya on the other hand. The Libyan faction called for a self-reliant United States of Africa in the spirit of the late Kwame Nkrumah. The Algeria, Nigeria and South Africa camp won the day.

The Africa Union was finalized in Maputo (Mozambique) in July 2003. It is modelled after the European Union (EU) with a Council of Ministers, a Commission, a pan-African Parliament and an African Court of Justice, while the secondary model is the Conference on Security, Stability, Development and Cooperation in Africa (CSSDCA) as formalized in the Kampala Document of the Africa Leadership Forum then led by Nigeria's president Olusegun Obasanjo of May 1991. The New Partnership for Africa's Development (NEPAD) is a merger of two previous initiatives: the millennium Action Plan for African Recovery (MAP) launched in February 2001 and sponsored by Thabo Mbeki (South Africa), Obasanjo and Abdelaziz Bouteflika (Algeria) and the Omega plan of Abdoulaye Wade (Senegal). The objective of NEPAD is to eradicate poverty through a new partnership between Africa and external donors regrouped within the 'Strategic Partnership for Africa'. It has identified eight sectors for priority action: good governance, infrastructure, education, health agriculture new information and communication technology energy and market access. A total of US $\$ 64$ billion has been earmarked to finance this program to which the U.S. has committed a $\$ 6$ billion aid package. NEPAD has been merged into AU's development program. NEPAD is a neo-liberal (neo-imperial) project based on the accelerated 
liberalization and privatization of African economies, with Western economic, financial and technical assistance and support. It is a mere poverty-reduction program that dovetails with similar programs promoted in Africa by the international financial institutions (International Monetary Fund/IMF and World Bank), Structural Adjustment Programs (SAPs) and Highly Indebted Developing Countries (HIDC) initiatives.

The AU and NEPAD cannot succeed because they are conceived from above (by the leadership) without popular input or support. They do not question the nature of the African state since they accept it as legitimate. Development based on these institutions is development against the people because they assume Africa can only develop by following the Western path in spite of its dismal performance. In addition, the AU and NEPAD are not informed by African culture, history and environment. Finally their goal is to remove the symptoms of the crises in these countries (poverty reduction) without addressing the root cause of the crises, namely the nature of the African state. In other words, the sole purpose of these institutions is to open Africa up for better exploitation by Western firms at the expense of the needs of Africans.

Economic independence based on the exploitation of Africa's resources with a view to improve the standard of living of Africans can only occur once the map of the continent is redrawn and the right leadership chosen by Africans for Africa.

According to Fundi wa Africa, the continent will be divided into five regions. These regions will make up the Federation of African States (Map 1: FAS). The new state of Kimit includes: Algeria, Libya, Morocco, Egypt, Tunisia and Western Sahara plus the Arab population of Mauritania, Northern Sudan and Northern Chad. Mali will include Benin, Burkina Faso, Cape Verde, Cote d'Ivoire, Gambia, Ghana, Guinea, Guinea-Bissau, Liberia, Mali, Niger, Nigeria, Senegal, Sierra Leone and Togo, plus the African population of Mauritania. Kongo will include Congo (DRC), Congo Republic, Cameroon, Southern Chad, Central African Republic, Equatorial Guinea, Gabon, Sao Tome \& Principe, Rwanda and Burundi. Kush includes southern Sudan, Ethiopia, Eritrea, Djibouti, Somalia-Somaliland, Kenya, Tanzania, Zanzibar, Seychelles, Uganda, and Comoros. Zimbabwe includes Angola, Botswana, Namibia, Malawi, Mozambique, Madagascar, Mauritius, Lesotho, Swaziland, South Africa, Zambia and Zimbabwe. The new federal capital city will be called Napata. It will not belong to any of the five states. These states will 
make up the Federation of African States (FAS). Each region will have a key player based on population and resources, for example, Kongo, Egypt, Ethiopia, Nigeria, and South Africa. All external economic relations will be conducted by the federal government.

\section{Economic Governance in the Federation of Airican States (FAS)}

In a co-written chapter titled 'Sub-Saharan Africa in Global Capitalism', Colin Leys and John S. Saul ask: Is Africa a victim of exploitation or of marginalization?

The short answer must be both. In the popular meaning of exploitation, Africa suffers acutely from exploitation: every packet of cheap Kenyan tea sold in New York, every overpriced tractor exported to Nigeria, every dollar of interest on ill-conceived and negligently supervised loans to African governments (interest that accrues to Western banks) - not to mention every diamond illegally purchased from warlords in Sierra Leone or Angola - benefits people in the West at the expense of Africa's impoverished populations (Saul 2005:20-21).

Africa operates in a hostile international capitalist system. This hostility will increase as Africans try to liberate themselves; hence the urgent need for the countries within the Federation to trade with each other, therefore creating an economic block.

In the Federation of African States, all economic activities will be geared toward two main goals: improving the standard of living of the majority of the people and strengthening the Federation. The Federation will no longer be a victim of exploitation or marginalization. In this spirit, particular emphasis will be placed on inter-state trade within the Federation. For example, FAS members that produce oil will sell it to other members while they, in turn, will purchase food items or textile products from these states. State corporations - manned by adequately trained managers, technicians and engineers - will be set up to manage and control key sectors of the economy such as utilities (water, electricity and telecommunications) and mining. Obviously, economic independence cannot be achieved without a rear-guard struggle from the contemporary beneficiaries. 
Map 1: FAS

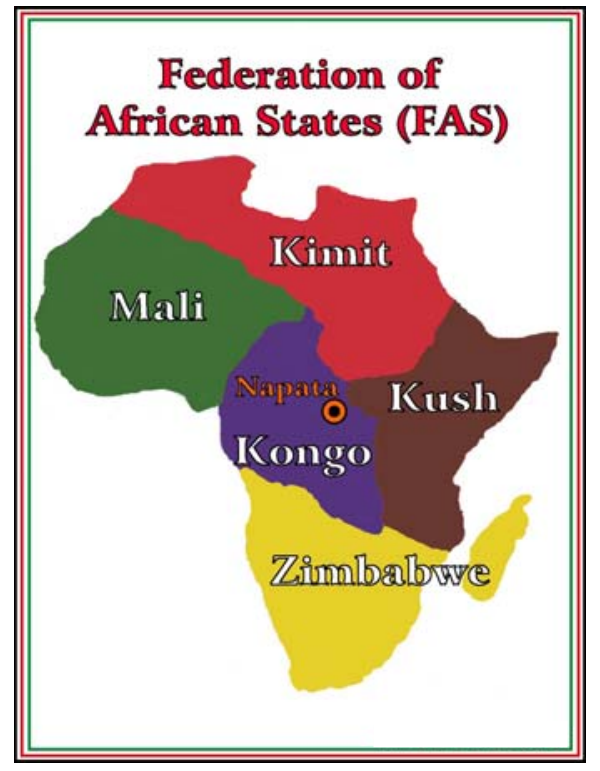

\section{Conclusion}

Without political and economic unity among African states, and without a political system based on the people's interests and informed by indigenous institutions, there can neither be a united Africa, nor an African renaissance. As the preceding discussion amply demonstrates, this calls on Africans to take control over their own development.

Kwame Nkrumah correctly observed in the early sixties that:

We are Africans first and last, and as Africans our best interests can only be served by uniting within an African Community (...) We in Africa have looked outward too long for the development of our economy and transportation. Let us begin to look inwards into the African Continent for all aspects of its development (...) We in Africa have untold agricultural, mineral, and water-power resources. These almost fabulous resources can be fully exploited and utilized in the interest of Africa and the African people, only if we develop them within a Union Government of African States (Nkrumah 1963:216, $217 \& 219)$. 
Africa's unity is still essential for development, peace and security. Godfrey Mwakikagile notes:

If the future of Africa lies in federation, that kind of federation could be a giant federation of numerous autonomous units which have replaced the modern African state in order to build, on a continental or sub-continental scale, a common market, establish a common currency, a common defence, and maybe even pursue a common foreign policy under some kind of central authority - including collective leadership on rotational basis - which Africans think is best for them (Mwakikagile 2001:121)

According to Mwalimu Julius Nyerere:

Africa...is isolated. Therefore, to develop, it will have to depend upon its own resources basically, internal resources, nationally, and Africa will have to depend upon Africa. The leadership of the future will have to devise, try to carry out policies of maximum national selfreliance and maximum collective self-reliance. They have no other choice. Hamna! [Kiswahili for there is none] (Saul 2005:159).

Against all odds, Africans have survived on the edge of starvation and poverty for five centuries. They must not just survive but overcome and triumph by becoming the initiators and owners of their own development - a process that entails a mental decolonization from dependency either on deities, leaders or Western countries and institutions. Africans can triumph over the destiny carved out for them by five centuries of capitalism's exploitation and marginalization of the continent. They have to harness their energies towards positive and constructive - rather than negative and destructive - pursuits: not to destroy each other but to fight against a common enemy which is dependency, poverty, disease and war. Africans must be incredibly bold and innovative if they are to, at last, control their natural resources and their destiny. They are definitely up to the challenge. Africa must solve its problems the African way on the basis of its own history, culture, tradition and environment.

\section{Reierences}

Arcton, Q-O., 2008, 'Cell Phone, A Tool of Violence in Kenya', National Public Radio 20 February; 5 minutes, 52 seconds.

Ake, C., 1996, Development and Democracy in Africa, Washington DC: The Brookings Institution.

Ake, C., 2000, The Feasibility of Democracy in Africa, Dakar: CODESRIA. 
Andresky, S., 1968, The African Predicament: A Study in the Pathology of Modernization, New York: Atherton Press.

Barnes, L., 1969, African Renaissance, Indianapolis: The Bob-Merrill Co.

Barry, B., 2001, Senegambia: Advocating Regional Historical Perspective, SEPHIS\# 1, 2 www.sephis.org/htm/publications.htm

Diop, B. B., Tobner, O. \& Verschave, F.X., 2005, Négrophobie, Paris: Editions des Arenes.

Editorial 2008, 'Kenya Ethnic Cleansing in Luoland', The Economist, February 7.

Kuhn, T., 1997, The Structure of Scientific Revolutions, Chicago: The University of Chicago Press.

Madsen, W., 1999, Genocide and Covert Operations in Africa 1993-1999, Lewiston: The Edwin Mellen Press.

Mamdani, M., 1996, Citizen and Subject: Contemporary Africa and the Legacy of Late Colonialism, Princeton, NJ: Princeton University Press.

Muiu wa Muen and Martin, Guy, A New Paradigme of the African State: Fundi wa Africa 9, New York: Palgrave Mcmilan- forthcomming.

Mwakikagile, G, 2001, The Modern African State: Quest for Transformation, Huntington, New York: Nova Science Publishers.

Nkrumah, K., 1963, Africa Must Unite, London: Panaf Books.

Nyerere, J. K., 'Reflections' in Reflections on Leadership in Africa: Forty Years after Independence: Essays in Honour of Mwalimu Julius K. Nyerere on the Occasion of his 75th Birthday, ed., Haroub Othman (Dar es Salaam: Institute of Development Studies, 2000).

Saul, J.S., 2005, The Next Liberation Struggle: Capitalism, Socialism and Democracy in Southern Africa, Scottsville, South Africa: University of KwaZulu-Natal Press.

Smith, S., 2003, Negrologie: Pourquoi l'Afrique Meurt, Paris: Calmann-Levy.

Tocqueville, A. de, 1963, 1835, De la Democratie en Amerique, Paris: Union Generale d'Editions.

U.N. Integrated Regional Information Network, 'Polio Campaign Succeeding despite Challenges', 8 August 2001, see http:www.allAfrica.com 